\title{
Optimization of the Production of 1-Phenylethanol Using Enzymes from Flowers of Tea (Camellia sinensis) Plants
}

\author{
Fang Dong ${ }^{1,+}$, Ying Zhou ${ }^{2,+}{ }^{+}$Lanting Zeng ${ }^{2}$, Naoharu Watanabe ${ }^{3}$, Xinguo Su ${ }^{1, *}$ \\ and Ziyin Yang ${ }^{2, *}$ \\ 1 Guangdong Food and Drug Vocational College, Longdongbei Road 321, Tianhe District, Guangzhou 510520, \\ China; dongfangxyz@163.com \\ 2 Key Laboratory of South China Agricultural Plant Molecular Analysis and Genetic Improvement \& \\ Guangdong Provincial Key Laboratory of Applied Botany, South China Botanical Garden, Chinese Academy \\ of Sciences, Xingke Road 723, Tianhe District, Guangzhou 510650, China; yzhou@scbg.ac.cn (Y.Z.); \\ zenglanting@scbg.ac.cn (L.Z.) \\ 3 Graduate School of Science and Technology, Shizuoka University, 3-5-1 Johoku, Naka-ku, \\ Hamamatsu 432-8561, Japan; watanabe.naoharu@shizuoka.ac.jp \\ * Correspondence: suxg@gdyzy.edu.cn (X.S.); zyyang@scbg.ac.cn (Z.Y.); Tel.: +86-20-2885-4755 (X.S.); \\ Tel./Fax: +86-20-3807-2989 (Z.Y.) \\ $\dagger$ These authors contributed equally to this work. \\ Academic Editor: Luca Forti \\ Received: 9 December 2016; Accepted: 10 January 2017; Published: 13 January 2017
}

\begin{abstract}
Phenylethanol (1PE) can be used as a fragrance in food flavoring and cosmetic industries and as an intermediate in the pharmaceutical industry. 1PE can be synthesized from acetophenone, and the cost of 1PE is higher than the cost of acetophenone. Therefore, it is important to establish an effective and low-cost approach for producing 1PE. Our previous studies found that tea (Camellia sinensis) flowers, which are an abundant and waste resource, contained enzymes that could transform acetophenone to 1PE. In the present study, we extracted crude enzymes from tea flowers and optimized the production conditions of 1PE using response surface methodology. The optimized conditions were an extraction $\mathrm{pH}$ of 7.0, a reaction $\mathrm{pH}$ of 5.3, a reaction temperature of $55^{\circ} \mathrm{C}$, a reaction time of $100 \mathrm{~min}$, a coenzyme NADPH concentration of $3.75 \mu \mathrm{mol} / \mathrm{mL}$ in the reaction assay, and a substrate acetophenone concentration of $1.25 \mu \mathrm{mol} / \mathrm{mL}$ in the reaction assay. The results provide essential information for future industrial 1PE production using plant-derived enzymes.
\end{abstract}

Keywords: aroma; Camellia sinensis; 1-phenylethanol; response surface methodology; tea; volatile

\section{Introduction}

So far, more than 1700 volatiles, which contribute to approximately $1 \%$ of all plant-specialized (secondary) metabolites currently known, have been identified in more than 90 plant families [1]. From a physiological standpoint, plant volatiles are mainly involved in protective effects against biotic stress by deterring herbivores and by attracting the enemies of herbivores, plant-plant or within-plant signaling, attractants for species-specific pollinators, and protective effects against abiotic stress possibly through direct or indirect improvement in resistance to damage by reactive oxygen species [1-3]. On the other hand, plant volatiles possess potential economic applications including improvement in food storage and flavor, sedation, and improvement in memory $[4,5]$. There are also increasing reports that plant volatiles are endowed with functions of human health benefits, especially a range of biological activities, which provides the basis of plant volatiles as lead compounds for drug discovery [6]. Owing to economic applications of plant volatiles, many attempts have been made to 
produce plant volatiles with high purity, such as direct extraction and isolation from plant materials, production by microorganism, chemical synthesis, and enzymatic synthesis. In generally, volatiles from plant-derived resources are accepted as "natural products". Direct extraction and isolation of volatiles from plants have a high cost, are time-consuming, and produce a low yield. Therefore, utilization of plant-derived enzymes is an alternative approach to producing "natural volatiles".

Tea (Camellia sinensis) is an important crop and cultivated in more than 30 countries including China, Japan, India, and Kenya. The most utilized part of tea plants is the leaf, which is generally used to make the most widely consumed beverage aside from water. However, less attention has been paid to tea flowers. Since asexual propagation was applied to tea plants, tea flowers became a "waste resource", that competes with tea leaves for water and nutrients. In China, over 4.0 billion kilograms of tea flowers are available annually (see the tea flowers web reference, after the reference list) [7]. In the past fifteen years, many researchers have isolated and identified functional metabolites in tea flowers, including catechins, caffeine [8,9], floratheasaponins [10-12], flavonol glycosides [13], polysaccharides [14], amino acids [15], and spermidine derivatives [16]. Besides non-volatile metabolites, volatile compounds have been detected in tea flowers, and volatile phenylpropanoids and benzenoids, especially 1-phenylethanol (1PE), have been identified as major volatiles [17-20]. In contrast to metabolites, enzymes in tea flowers have attracted less attention, and only proteases [21] and some enzymes involved in the formation of volatiles [18,19] have been characterized in tea flowers.

In our previous studies [17-20], tea flowers were found to contain a high amount of 1PE, which can be used as a fragrance in the food flavoring and cosmetic industries and as an intermediate in the pharmaceutical industry. However, it is unfeasible to extract and purify 1PE from tea flowers because doing so comes at a high cost, is time consuming, and produces a low yield. We have demonstrated that tea flowers contain enzymes that can transform from acetophenone to 1PE $[17,20]$. The cost of the substrate acetophenone is much lower than the cost of 1PE. In the present study, we established a synthetic system of 1PE production using acetophenone as a substrate and enzymes from tea flowers, and optimized the production conditions of 1PE using response surface methodology.

\section{Results and Discussion}

Response surface methodology with six factors (extraction $\mathrm{pH}$, reaction $\mathrm{pH}$, reaction temperature, reaction time, coenzyme NADPH concentration, and substrate acetophenone concentration) at five levels was employed to examine the effects of these parameters on 1PE yield (Table 1). There were 58 runs in the design and response value was Y1 (1PE production) (Table 2). Using response surface methodology, the four factors were optimized to acquire the highest 1PE yield with an enzyme extraction $\mathrm{pH}$ of 7.0, an enzyme reaction time of $100 \mathrm{~min}$, a coenzyme NADPH concentration of $3.75 \mu \mathrm{mol} / \mathrm{mL}$ in the reaction assay $(1.5 \mu \mathrm{mol}$ in a $400 \mu \mathrm{L}$ reaction assay), and a substrate acetophenone concentration of $1.25 \mu \mathrm{mol} / \mathrm{mL}$ in the reaction assay $(0.5 \mu \mathrm{mol}$ in a $400 \mu \mathrm{L}$ reaction assay) (Figure 1). However, the other two factors including reaction $\mathrm{pH}$ and reaction temperature need to be further optimized. Therefore, the reaction $\mathrm{pH}$ ranging from 4.5 to 5.3 and the reaction temperature ranging from $40{ }^{\circ} \mathrm{C}$ to $70^{\circ} \mathrm{C}$ were further investigated. The results showed that the highest 1PE yield was obtained under the conditions of a reaction $\mathrm{pH}$ of 5.3 and a reaction temperature of $55^{\circ} \mathrm{C}$ (Figure 2). Based on calculations of the standard 1PE curve (Figure 3), the $80.8 \mathrm{nmol}$ of 1PE was produced from $500 \mathrm{nmol}$ of acetophenone in the optimized condition. Furthermore, the enzymes from tea flowers mainly produced $(R)-1 \mathrm{PE}$ from acetophenone (Figure 4). In future industrial applications, considering cost, the additional amount of acetophenone can be reduced, because the substrate amount did not significantly affect 1PE yield (Figure 1). In addition, due to its relatively low boiling point, acetophenone may be easily released under a relatively high reaction temperature $\left(55^{\circ} \mathrm{C}\right)$ [17]. Further study on the improvement of the complete utilization of acetophenone as a substrate will be helpful for increases in yield and reductions in cost in industrial applications. 
Table 1. Factors and levels of response surface methodology.

\begin{tabular}{lccccc}
\hline Factors (Coded Level) & $\mathbf{- 2 . 3 7 8 4 1}$ & $\mathbf{- 1}$ & $\mathbf{0}$ & $\mathbf{1}$ & $\mathbf{2 . 3 7 8 4 1}$ \\
\hline $\mathrm{X} 1$ : Enzyme extraction $\mathrm{pH}$ & 5.3 & 6 & 6.5 & 7 & 7.7 \\
\hline $\mathrm{X}$ : Enzymatic reaction $\mathrm{pH}$ & 5.3 & 6 & 6.5 & 7 & 7.7 \\
\hline $\mathrm{X}$ : Enzymatic reaction temperature $\left({ }^{\circ} \mathrm{C}\right)$ & 25 & 30 & 34 & 38 & 44 \\
\hline $\mathrm{X} 4:$ Enzymatic reaction time $(\mathrm{min})$ & 12.5 & 40 & 60 & 80 & 107.5 \\
\hline $\begin{array}{l}\mathrm{X} 5: \mathrm{NADPH}(\text { coenzyme) final concentration } \\
\mu \mathrm{mol}(\text { in } 400 \mu \mathrm{L} \text { reaction assay) }\end{array}$ & 0.3 & 0.7 & 1 & 1.3 & 1.7 \\
\hline $\begin{array}{l}\mathrm{X} 6:\left[{ }^{2} \mathrm{H}_{5} \text { ]ring-acetophenone }(\text { substrate) final }\right. \\
\text { concentration } \mu \mathrm{mol}(\text { in } 400 \mu \mathrm{L} \text { reaction assay) }\end{array}$ & 0.16 & 0.3 & 0.4 & 0.5 & 0.64 \\
\hline
\end{tabular}

Table 2. Response surface methodology for different conditions of 1PE production and 1PE yield.

\begin{tabular}{|c|c|c|c|c|c|c|c|}
\hline Run & $\mathrm{X} 1$ & $\mathrm{X} 2$ & $\mathrm{X} 3$ & $X 4$ & $\mathrm{X} 5$ & $\mathrm{X} 6$ & Y1 a (1PE Yield) \\
\hline 1 & -1 & -1 & -1 & -1 & -1 & -1 & 0.758559371 \\
\hline 2 & -1 & -1 & -1 & -1 & 1 & 1 & 0.846748345 \\
\hline 3 & -1 & -1 & -1 & 1 & -1 & 1 & 1.153593462 \\
\hline 4 & -1 & -1 & -1 & 1 & 1 & -1 & 1.150490973 \\
\hline 5 & -1 & -1 & 1 & -1 & -1 & 1 & 1.025881547 \\
\hline 6 & -1 & -1 & 1 & -1 & 1 & -1 & 1.154783234 \\
\hline 7 & -1 & -1 & 1 & 1 & -1 & -1 & 1.586798695 \\
\hline 8 & -1 & -1 & 1 & 1 & 1 & 1 & 1.452172855 \\
\hline 9 & -1 & 1 & -1 & -1 & -1 & 1 & 0.447787063 \\
\hline 10 & -1 & 1 & -1 & -1 & 1 & -1 & 0.508368068 \\
\hline 11 & -1 & 1 & -1 & 1 & -1 & -1 & 0.765378069 \\
\hline 12 & -1 & 1 & -1 & 1 & 1 & 1 & 0.631801149 \\
\hline 13 & -1 & 1 & 1 & -1 & -1 & -1 & 0.620733457 \\
\hline 14 & -1 & 1 & 1 & -1 & 1 & 1 & 0.770290718 \\
\hline 15 & -1 & 1 & 1 & 1 & -1 & 1 & 1.05186958 \\
\hline 16 & -1 & 1 & 1 & 1 & 1 & -1 & 1.269535781 \\
\hline 17 & 1 & -1 & -1 & -1 & -1 & 1 & 0.828065574 \\
\hline 18 & 1 & -1 & -1 & -1 & 1 & -1 & 0.953103788 \\
\hline 19 & 1 & -1 & -1 & 1 & -1 & -1 & 1.110510204 \\
\hline 20 & 1 & -1 & -1 & 1 & 1 & 1 & 2.091175436 \\
\hline 21 & 1 & -1 & 1 & -1 & -1 & -1 & 1.490051857 \\
\hline 22 & 1 & -1 & 1 & -1 & 1 & 1 & 1.525848802 \\
\hline 23 & 1 & -1 & 1 & 1 & -1 & 1 & 1.838977526 \\
\hline 24 & 1 & -1 & 1 & 1 & 1 & -1 & 2.564189622 \\
\hline 25 & 1 & 1 & -1 & -1 & -1 & -1 & 0.652233718 \\
\hline 26 & 1 & 1 & -1 & -1 & 1 & 1 & 0.782094508 \\
\hline 27 & 1 & 1 & -1 & 1 & -1 & 1 & 0.937807534 \\
\hline 28 & 1 & 1 & -1 & 1 & 1 & -1 & 1.035549206 \\
\hline 29 & 1 & 1 & 1 & -1 & -1 & 1 & 1.105724121 \\
\hline 30 & 1 & 1 & 1 & -1 & 1 & -1 & 1.009265424 \\
\hline 31 & 1 & 1 & 1 & 1 & -1 & -1 & 1.500473779 \\
\hline 32 & 1 & 1 & 1 & 1 & 1 & 1 & 1.35519365 \\
\hline 33 & -2.37841 & 0 & 0 & 0 & 0 & 0 & 0.481731606 \\
\hline 34 & 2.378414 & 0 & 0 & 0 & 0 & 0 & 0.698984848 \\
\hline 35 & 0 & -2.37841 & 0 & 0 & 0 & 0 & 1.570230689 \\
\hline 36 & 0 & 2.378414 & 0 & 0 & 0 & 0 & 0.722668367 \\
\hline 37 & 0 & 0 & -2.37841 & 0 & 0 & 0 & 0.896550121 \\
\hline 38 & 0 & 0 & 2.378414 & 0 & 0 & 0 & 2.489739273 \\
\hline 39 & 0 & 0 & 0 & -2.37841 & 0 & 0 & 0.548374842 \\
\hline 40 & 0 & 0 & 0 & 2.378414 & 0 & 0 & 1.370597491 \\
\hline 41 & 0 & 0 & 0 & 0 & -2.37841 & 0 & 1.263502722 \\
\hline 42 & 0 & 0 & 0 & 0 & 2.378414 & 0 & 1.074987099 \\
\hline 43 & 0 & 0 & 0 & 0 & 0 & -2.37841 & 1.103270031 \\
\hline 44 & 0 & 0 & 0 & 0 & 0 & 2.378414 & 1.421635721 \\
\hline 45 & 0 & 0 & 0 & 0 & 0 & 0 & 1.226729653 \\
\hline 46 & 0 & 0 & 0 & 0 & 0 & 0 & 1.377231877 \\
\hline 47 & 0 & 0 & 0 & 0 & 0 & 0 & 1.242217123 \\
\hline 48 & 0 & 0 & 0 & 0 & 0 & 0 & 1.291999792 \\
\hline 49 & 0 & 0 & 0 & 0 & 0 & 0 & 1.273597247 \\
\hline
\end{tabular}


Table 2. Cont.

\begin{tabular}{cccccccc}
\hline Run & $\mathbf{X 1}$ & $\mathbf{X} \mathbf{2}$ & $\mathbf{X 3}$ & $\mathbf{X} \mathbf{4}$ & $\mathbf{X 5}$ & $\mathbf{X 6}$ & Y1 $^{\text {a }}$ (1PE Yield) \\
\hline 50 & 0 & 0 & 0 & 0 & 0 & 0 & 1.249548763 \\
51 & 0 & 0 & 0 & 0 & 0 & 0 & 1.224737373 \\
52 & 0 & 0 & 0 & 0 & 0 & 0 & 1.28414853 \\
53 & 0 & 0 & 0 & 0 & 0 & 0 & 1.263331053 \\
54 & 0 & 0 & 0 & 0 & 0 & 0 & 1.250814756 \\
55 & 0 & 0 & 0 & 0 & 0 & 0 & 1.216741671 \\
56 & 0 & 0 & 0 & 0 & 0 & 0 & 1.308596416 \\
57 & 0 & 0 & 0 & 0 & 0 & 0 & 1.225345486 \\
58 & 0 & 0 & 0 & 0 & 0 & 0 & 1.360042105 \\
\hline
\end{tabular}

${ }^{a}$ The formed $\left[{ }^{2} \mathrm{H}_{5}\right]$ ring-1PE amount (1PE yield) was determined by the peak area ratio of the analyte to an internal standard (ethyl $n$-decanoate). Peak areas of the internal standard were calculated as the summation of $m / z 88$ and $m / z$ 101. $\left[{ }^{2} \mathrm{H}_{5}\right]$ ring-1PE peak areas were calculated as the summation of $m / z 84, m / z 112$, and $m / z 127$.

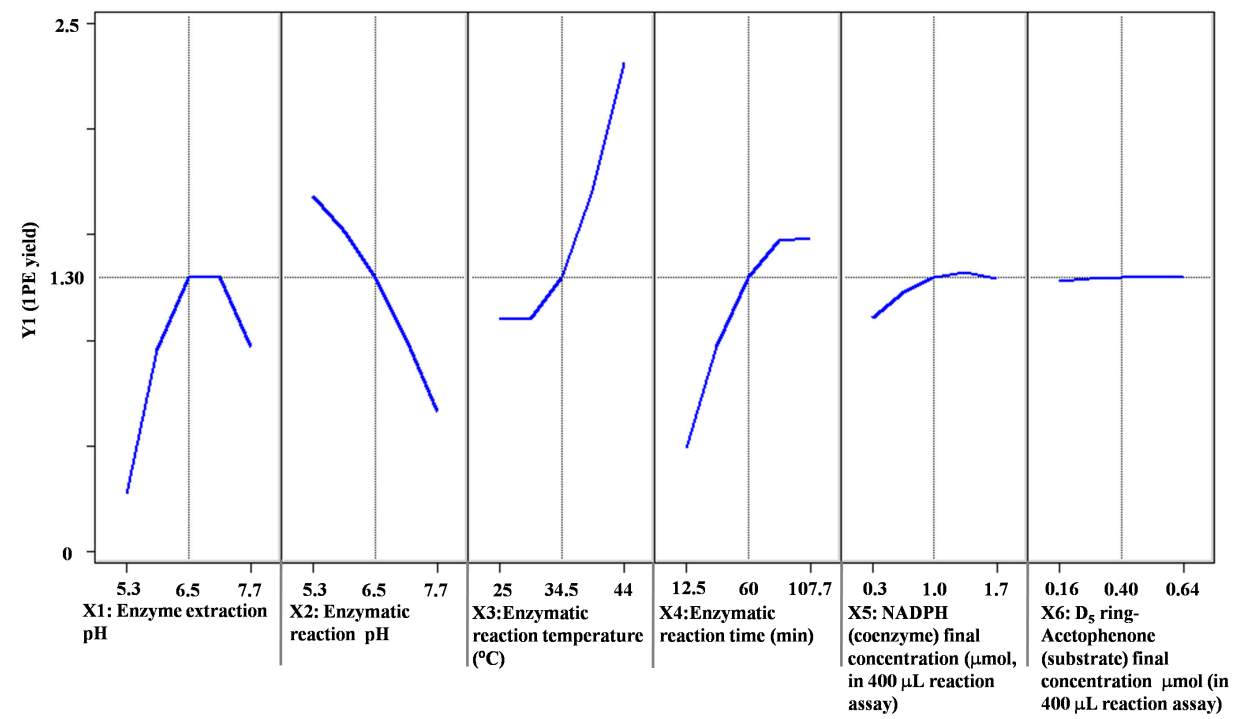

Figure 1. Prediction profilers of the effects of six variables (X1-X6) on 1PE yield. 1PE yield was determined by the peak area ratio of $\left[{ }^{2} \mathrm{H}_{5}\right]$ ring-1PE to an internal standard (ethyl $n$-decanoate). Peak areas of the internal standard were calculated as the summation of $m / z 88$ and $m / z$ 101. $\left[{ }^{2} \mathrm{H}_{5}\right.$ ] ring-1PE peak areas were calculated as the summation of $m / z 84, m / z 112$, and $m / z 127$.

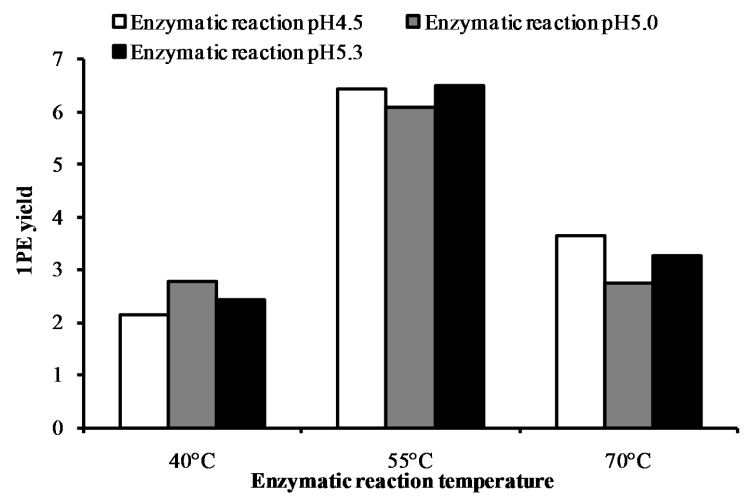

Figure 2. Effects of the enzymatic reaction $\mathrm{pH}(4.5-5.3)$ and the enzymatic reaction temperature $\left(40-70{ }^{\circ} \mathrm{C}\right)$ on $1 \mathrm{PE}$ yield. $1 \mathrm{PE}$ yield was determined by the peak area ratio of $\left[{ }^{2} \mathrm{H}_{5}\right]$ ring- $1 \mathrm{PE}$ to an internal standard (ethyl $n$-decanoate). Peak areas of the internal standard were calculated as the summation of $m / z 88$ and $m / z$ 101. $\left[{ }^{2} \mathrm{H}_{5}\right]$ ring-1PE peak areas were calculated as the summation of $m / z 84, m / z 112$, and $m / z 127$. 


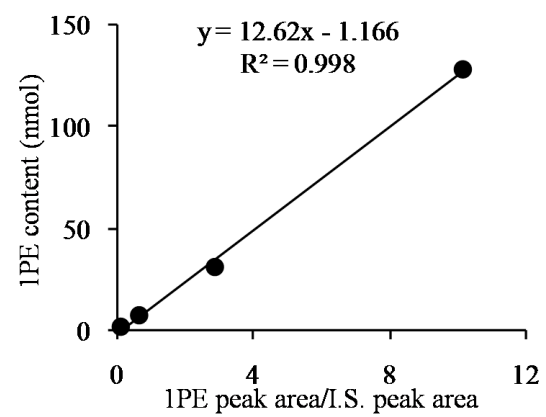

Figure 3. Standard 1PE curve using ethyl $n$-decanoate as an internal standard (IS). $X$-axis shows the GC-MS peak area ratio of $1 \mathrm{PE}$ to the IS. $Y$-axis shows $1 \mathrm{PE}$ content. The IS content was $5 \mathrm{nmol}$.

$1 \mathrm{PE}$ can be used as a fragrance in the food flavoring and cosmetic industries and as an intermediate in the pharmaceutical industry. Some microorganisms including the Azoarcus sp. strain EbN1 and Geotrichum candidum NBRC 4597 were found to contain enzymes being able to convert acetophenone to 1PE [22,23]. However, such enzymes were not characterized in plants. In our previous study, using traditional protein chromatography, the two types of partially purified enzymes were proposed to be responsible for formations of $(R)-1 \mathrm{PE}$ and (S)-1PE from acetophenone, respectively [20]. Furthermore, the major 1PE synthetic enzymes were to produce the $(R)-1 \mathrm{PE}$ of tea flowers in vivo [17]. The present study characterized the in vitro properties of 1PE synthetic enzymes from tea flowers, which showed a higher activity under acidic condition and a higher temperature (Figures 1 and 2). In addition, a medium $\mathrm{pH}$ extraction buffer was used to obtain 1PE synthetic enzymes with high activity (Figure 1).

Although 1PE was accumulated in tea flowers in contrast to other Camellia plants [17], it is

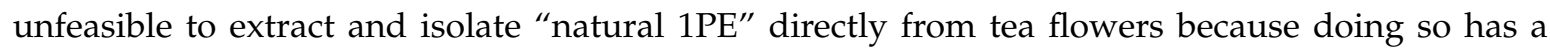
high cost, is time consuming, and produces a low yield. Therefore, 1PE synthetic enzymes in

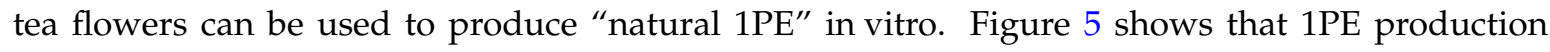
using enzymes from tea flowers was significantly higher than that from tea flowers (Figure 5). It is important to improve the performance of the enzyme synthesis systems and to increase the yield of the target product without increasing the cost. Response surface methodology is a combination of statistical and mathematical techniques by which a response is affected by several variables, and the aim is to optimize this response [24]. In recent years, response surface methodology has been widely applied to the optimization of biochemical processes, such as the enzymatic synthesis of fatty esters [25], alkaline protease production from Bacillus mojavensis in a bioreactor [26], the synthesis of butylgalactoside using $\beta$-galactosidase from Aspergillus oryzae [27], bioconversion from 2-phenylethanol to phenylacetaldehyde in a two-phase fed-batch system [28], the production of cholesterol oxidase using Rhodococcusequi no. 23 [29], and the production of phytase by Pichia anomala [30]. Response surface methodology was employed not only for the optimization of production but also for the determination of kinetic constants, enzyme stability, and kinetics [31]. In the present study, response surface methodology was used to optimize 1PE production using plant-derived enzymes. As there were six variables from extraction and reaction processes that possibly influenced 1PE yield (Table 1), the use of response surface methodology could reduce experimental runs from multiple variables and quickly obtain optimized conditions (Figures 1 and 2). This study provided a good example of the optimization of functional metabolite production using plant-derived enzymes. 


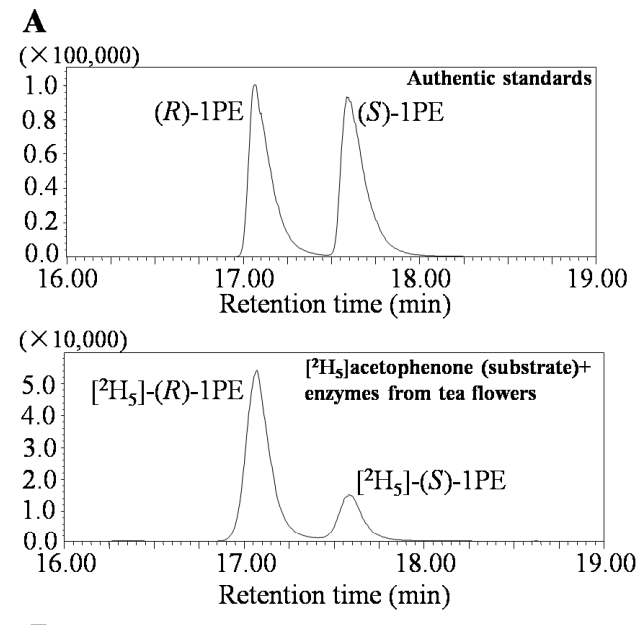

$\mathbf{B}$

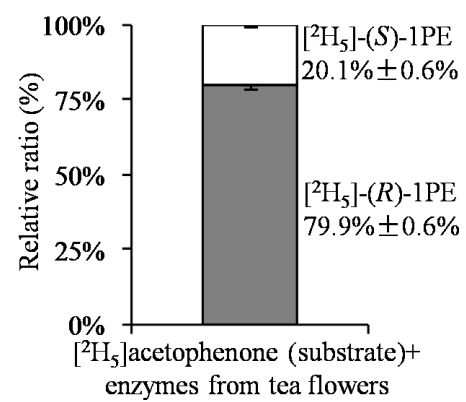

Figure 4. Identification of (R)-1PE and (S)-1PE from biotransformation using enzymes from tea flowers. (A) GC-MS equipped with an InertCap CHIRAMIX column was employed to determine $(R)-1 P E$ and (S)-1PE; (B) Data are expressed as mean \pm S.D. $(n=5)$.

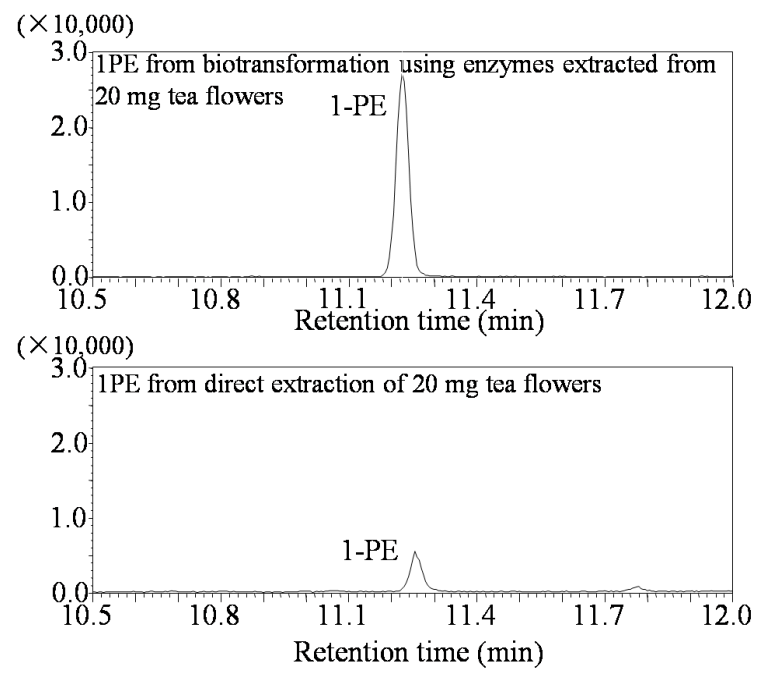

Figure 5. GC-MS identification of 1PE products from biotransformation using enzymes from tea flowers and direct extraction of tea flowers.

\section{Materials and Methods}

\subsection{Extraction of Crude 1PE Synthetic Enzymes from Tea Flowers}

Tea flowers (C. sinensis var. Yabukita) at stage-3 (the flower is fully open) contain a higher amount of 1PE [17], and these tea flowers were used to extract crude 1PE synthetic enzymes. 
One gram of finely powdered tea flowers at stage- 3 crushed by a Multi-Beads Shocker (2000 rpm, $15 \mathrm{~s}$ ) were added to $0.3 \mathrm{~g}$ of polyvinylpolypyrrolidone and $20 \mathrm{mg}$ of 3-[(3-cholamidopropyl)dimethylamino]-1-propanesulfonate, homogenized in $10 \mathrm{~mL}$ of cold buffer A (100 mM potassium phosphate buffer containing $1 \%$ glycerol and $1 \mathrm{mM}$ ethylenediamine tetraacetic acid (EDTA)) under ice, and centrifuged $\left(26,740 \times g, 4^{\circ} \mathrm{C}, 20 \mathrm{~min}\right)$. The supernatant was centrifuged again $\left(26,740 \times g, 4{ }^{\circ} \mathrm{C}\right.$, $20 \mathrm{~min}$ ) to remove suspended substances, then loaded on a PD-10 desalting column (GE Healthcare Bio-Sciences, Piscataway, NJ, USA), and eluted using $10 \mathrm{mM}$ potassium phosphate buffer containing $0.1 \%$ glycerol and $0.1 \mathrm{mM}$ EDTA. The eluate was used as a crude enzyme solution.

\subsection{The Optimization of Production Conditions of 1PE Using Crude 1PE Synthetic Enzymes from Tea Flowers}

To exclude the possible effects from acetophenone and 1PE that occur in a crude enzyme solution, the substrate in the enzyme assay used labeled $\left[{ }^{2} \mathrm{H}_{5}\right.$ ]ring-acetophenone $(98 \%$, Cambridge Isotope Laboratories, Inc., Andover, MA, USA). The reaction mixture contained $200 \mu \mathrm{L}$ of enzyme solution, $50 \mu \mathrm{L}$ of substrate (labeled $\left[{ }^{2} \mathrm{H}_{5}\right]$ ring-acetophenone), $50 \mu \mathrm{L}$ of coenzyme (NADPH), and $100 \mu \mathrm{L}$ of a $100 \mathrm{mM}$ potassium phosphate buffer. The different reaction conditions (Table 1) were investigated. Afterwards, $5 \mathrm{nmol}$ of ethyl $n$-decanoate as an internal standard was added. The reaction products were extracted with $0.4 \mathrm{~mL}$ of hexane/ethyl acetate (1:1) and centrifuged $\left(10,000 \times g, 4{ }^{\circ} \mathrm{C}, 3 \mathrm{~min}\right)$. The supernatant was dried over anhydrous sodium sulfate. Samples were then analyzed by GC-MS, which was same as the previous study [20]. The temperature of the injector was $230^{\circ} \mathrm{C}$. The GC was equipped with a capillary SUPELCOWAX ${ }^{\mathrm{TM}} 10$ column (Supelco Inc., Bellefonte, PA, USA, $30 \mathrm{~m} \times 0.25 \mathrm{~mm}$ I.D., $0.25 \mu \mathrm{m}$ film thickness). Helium was used as a carrier gas at a flow rate of $1.6 \mathrm{~mL} / \mathrm{min}$. The GC oven was maintained at $60^{\circ} \mathrm{C}$ for $3 \mathrm{~min}$. The temperature of the oven was programmed at $40^{\circ} \mathrm{C} / \mathrm{min}$ to $180^{\circ} \mathrm{C}$ and then at $10^{\circ} \mathrm{C} / \mathrm{min}$ to $240{ }^{\circ} \mathrm{C}$, and kept at this temperature for $3 \mathrm{~min}$. The mass spectrometry was operated by the full scan mode (mass range $\mathrm{m} / z$ 70-200). Characteristic ions of $\left[{ }^{2} \mathrm{H}_{5}\right]$ ring-1PE were $m / z 84, m / z 112$, and $m / z 127$.

\subsection{Analysis of (R)-1PE and (S)-1PE Products from Biotransformation Using Enzymes from Tea Flowers}

GC-MS equipped with an InertCap CHIRAMIX column $(30 \mathrm{~m} \times 0.25 \mathrm{~mm} \times 0.25 \mu \mathrm{m}$, GL Sciences, Inc., Torrence, CA, USA) was employed to determine (R)-1PE and (S)-1PE. The injector temperature was $180^{\circ} \mathrm{C}$, splitless mode was used with a splitless time of $1 \mathrm{~min}$, and helium was the carrier gas with a velocity of $1.0 \mathrm{~mL} / \mathrm{min}$. The GC temperatures were as follows: $60^{\circ} \mathrm{C}$ for $2 \mathrm{~min}$, a ramp of $40{ }^{\circ} \mathrm{C} / \mathrm{min}$ to $105^{\circ} \mathrm{C}$, followed by $2{ }^{\circ} \mathrm{C} / \mathrm{min}$ to $137^{\circ} \mathrm{C}$, then $80^{\circ} \mathrm{C} / \mathrm{min}$ to $180^{\circ} \mathrm{C}$, and $180{ }^{\circ} \mathrm{C}$ for $10 \mathrm{~min}$.

\subsection{Statistical Analysis}

Response surface methodology was processed using the software package SAS v8.0 (SAS Institute Inc., Cary, NC, USA).

\section{Conclusions}

Our present study characterized the in vitro properties of 1PE synthetic enzymes from tea flowers, suggesting that the enzymes were thermostable, and the enzyme extraction $\mathrm{pH}$ and the reaction $\mathrm{pH}$ were different at the highest enzyme activity. Furthermore, this study established an effective and low-cost system for producing $1 \mathrm{PE}$, with the following optimized conditions: an extraction $\mathrm{pH}$ of 7.0, a reaction $\mathrm{pH}$ of 5.3 , a reaction temperature of $55^{\circ} \mathrm{C}$, a reaction time of $100 \mathrm{~min}$, a coenzyme NADPH concentration of $3.75 \mu \mathrm{mol} / \mathrm{mL}$ in the reaction assay, and a substrate acetophenone concentration of $1.25 \mu \mathrm{mol} / \mathrm{mL}$ in the reaction assay. These results provide essential information for future industrial 1PE production using plant-derived enzymes. In addition, this will contribute to future applications of functional proteins from abundant and waste tea flower resources. 
Acknowledgments: This study was supported by the financial support from the National Natural Science Foundation for Young Scholars of China (31601787 and 31500244), the Guangdong Natural Science Foundation (2016A030313652, 2014A030310131, and 2014A030313767), the Science and Technology Project of Guangdong Province (2013B090600002), and the "100 Talents Programme of the Chinese Academy of Sciences" (Y321011001 and 201209).

Author Contributions: Z.Y. and N.W. conceived the experiments. F.D., Z.Y., Y.Z., L.Z., and X.S. conducted the experiments. Z.Y. and F.D. analyzed the results. F.D. and Z.Y. wrote the manuscript. All authors reviewed the manuscript.

Conflicts of Interest: The authors declare no conflict of interest.

\section{References}

1. Pichersky, E.; Gershenzon, J. The formation and function of plant volatiles: Perfumes for pollinator attraction and defense. Curr. Opin. Plant Biol. 2002, 5, 237-243. [CrossRef]

2. Dong, F.; Fu, X.M.; Watanabe, N.; Su, X.G.; Yang, Z.Y. Recent advances in the emission and functions of plant vegetative volatiles. Molecules 2016, 21, 124. [CrossRef] [PubMed]

3. Vickers, C.E.; Gershenzon, J.; Lerdau, M.T.; Loreto, F. A unified mechanism of action for volatile isoprenoids in plant abiotic stress. Nat. Chem. Biol. 2009, 5, 283-291. [CrossRef] [PubMed]

4. Rasch, B.; Büchel, C.; Gais, S.; Born, J. Odor cues during slow-wave sleep prompt declarative memory consolidation. Science 2007, 315, 1426-1429. [CrossRef] [PubMed]

5. Schwab, W.; Davidovich-Rikanati, R.; Lewinsohn, E. Biosynthesis of plant-derived flavor compounds. Plant J. 2008, 54, 712-732. [CrossRef] [PubMed]

6. Maffei, M.E.; Gertsch, J.; Appendino, G. Plant volatiles: Production, function and pharmacology. Nat. Prod. Rep. 2011, 28, 1359-1380. [CrossRef] [PubMed]

7. Tea Flower Web Reference. Available online: http://baike.baidu.com/link?url=kuRD4sm6LdTlTDfdYAMw JQaa_2QPoUi4_Hh8EWySpXiGJax6pFevl1IhtGcjqEqz9ZuShxXFoNeNccPNv47ME_ (accessed on 1 December 2016).

8. Lin, Y.S.; Wu, S.S.; Lin, J.K. Determination of tea polyphenols and caffeine in tea flowers (Camellia sinensis) and their hydroxyl radical scavenging and nitric oxide suppressing effects. J. Agric. Food Chem. 2003, 51, 975-978. [CrossRef] [PubMed]

9. Yang, Z.Y.; Xu, Y.; Jie, G.L.; He, P.M.; Tu, Y.Y. Study on the antioxidant activity of tea flowers (Camellia sinensis). Asia Pac. J. Clin. Nutr. 2007, 16 (Suppl. S1), 148-152. [PubMed]

10. Yoshikawa, M.; Morikawa, T.; Yamamoto, K.; Kato, Y.; Nagatomo, A.; Matsuda, H. Floratheasaponins A-C, acylated oleanane-type triterpene oligoglycosides with anti-hyperlipidemic activities from flowers of the tea plant (Camellia sinensis). J. Nat. Prod. 2005, 68, 1360-1365. [CrossRef] [PubMed]

11. Yoshikawa, M.; Nakamura, S.; Kato, Y.; Matsuhira, K.; Matsuda, H. Medicinal flowers. XIV. New acylated oleanane-type triterpene oligoglycosides with antiallergic activity from flower buds of Chinese tea plant (Camellia sinensis). Chem. Pharm. Bull. 2007, 55, 598-605. [CrossRef] [PubMed]

12. Morikawa, T.; Miyake, S.; Miki, Y.; Ninomiya, K.; Yoshikawa, M.; Muraoka, O. Quantitative analysis of acylated oleananetype triterpene saponins, chakasaponins I-III and floratheasaponins A-F, in the flower buds of Camellia sinensis from different regional origins. J. Nat. Med. 2012, 66, 608-613. [CrossRef] [PubMed]

13. Yang, Z.Y.; Tu, Y.Y.; Baldermann, S.; Dong, F.; Xu, Y.; Watanabe, N. Isolation and identification of compounds from the ethanolic extract of flowers of the tea (Camellia sinensis) plant and their contribution to the antioxidant capacity. LWT Food Sci. Technol. 2009, 42, 1439-1443. [CrossRef]

14. Wang, Y.; Yang, Z.; Wei, X. Sugar compositions, $\alpha$-glucosidase inhibitory and amylase inhibitory activities of polysaccharides from leaves and flowers of Camellia sinensis obtained by different extraction methods. Int. J. Biol. Macromol. 2010, 47, 534-539. [CrossRef] [PubMed]

15. Wang, L.; Xu, R.; Hu, B.; Li, W.; Sun, Y.; Tu, Y.; Zeng, X. Analysis of free amino acids in Chinese teas and flower of tea plant by high performance liquid chromatography combined with solid-phase extraction. Food Chem. 2010, 123, 1259-1266. [CrossRef]

16. Yang, Z.Y.; Dong, F.; Baldermann, S.; Murata, A.; Tu, Y.Y.; Asai, T.; Watanabe, N. Isolation and identification of spermidine derivatives in flowers of tea (Camellia sinensis) plants and their distributions in floral organs. J. Sci. Food Agric. 2012, 92, 2128-2132. [CrossRef] [PubMed] 
17. Dong, F.; Yang, Z.Y.; Baldermann, S.; Kajitani, Y.; Ota, S.; Kasuga, H.; Imazeki, Y.; Ohnishi, T.; Watanabe, N. Characterization of L-phenylalanine metabolism to acetophenone and 1-phenylethanol in the flowers of Camellia sinensis using stable isotope labeling. J. Plant Physiol. 2012, 169, 217-225. [CrossRef] [PubMed]

18. Zhou, Y.; Dong, F.; Kunimasa, A.; Zhang, Y.; Cheng, S.; Lu, J.; Zhang, L.; Murata, A.; Mayer, F.; Fleischmann, P.; et al. Occurrence of glycosidically conjugated 1-phenylethanol and its hydrolase $\beta$-primeverosidase in tea (Camellia sinensis) flowers. J. Agric. Food Chem. 2014, 62, 8042-8050. [CrossRef] [PubMed]

19. Zhou, Y.; Zhang, L.; Gui, J.D.; Dong, F.; Cheng, S.; Mei, X.; Zhang, L.Y.; Li, Y.Q.; Su, X.G.; Baldermann, S.; et al. Molecular cloning and characterization of a short chain dehydrogenase showing activity with volatile compounds isolated from Camellia sinensis. Plant Mol. Biol. Rep. 2015, 33, 253-263. [CrossRef]

20. Dong, F.; Zhou, Y.; Zeng, L.T.; Peng, Q.Y.; Zhang, L.; Su, X.G.; Watanabe, N.; Yang, Z.Y. Elucidation of differential accumulation of 1-phenylethanol in flowers and leaves of tea (Camellia sinensis) plants. Molecules 2016, 21, 1106. [CrossRef] [PubMed]

21. Chen, Y.Y.; Fu, X.M.; Mei, X.; Zhou, Y.; Du, B.; Tu, Y.Y.; Yang, Z.Y. Characterization of functional proteases from flowers of tea (Camellia sinensis) plants. J. Funct. Foods 2016, 25, 149-159. [CrossRef]

22. Höffken, H.W.; Duong, M.; Friedrich, T.; Breuer, M.; Hauer, B.; Reinhardt, R.; Rabus, R.; Heider, J. Crystal structure and enzyme kinetics of the (S)-specific 1-phenylethanol dehydrogenase of the denitrifying bacterium Strain EbN1. Biochemistry 2006, 45, 82-93. [CrossRef] [PubMed]

23. Yamamoto, T.; Nakata, Y.; Cao, C.; Sugiyama, Y.; Asanuma, Y.; Kanamaru, S.; Matsuda, T. Acetophenone reductase with extreme stability against a high concentration of organic compounds or an elevated temperature. Appl. Microbiol. Biotechnol. 2013, 97, 10413-10421. [CrossRef] [PubMed]

24. Baş, D.; Boyacı, İ.H. Modeling and optimization I: Usability of response surface methodology. J. Food Eng. 2007, 78, 836-845. [CrossRef]

25. Aracil, J.; Garcia, T.; Sanchez, N.; Matinez, M. Enzymatic synthesis of fatty esters. Part II. Optimization studies. Enzyme Microb. Technol. 1999, 25, 591-597.

26. Beg, Q.K.; Sahai, V.; Gupta, R. Statistical media optimization and alkaline protease production from Bacillus mojavensis in a bioreactor. Process Biochem. 2003, 39, 203-209. [CrossRef]

27. Ismail, A.; Linder, M.; Ghoul, M. Optimization of butylgalactoside synthesis by $\alpha$-galactosidase from Aspergillus oryzae. Enzyme Microb. Technol. 1999, 25, 208-213. [CrossRef]

28. Çelik, D.; Bayraktar, E.; Mehmetoğlu, Ü. Biotransformation of 2-phenylethanol to phenylacetaldehyde in a two-phase fed-batch system. Biochem. Eng. J. 2004, 17, 5-13. [CrossRef]

29. Lee, M.T.; Chen, W.C.; Chou, C.C. Maximization of cholesterol oxidase production by Rhodococcusequi no. 23 by using response surface methodology. Biotechnol. Appl. Biochem. 1998, 28, 229-233. [PubMed]

30. Vohra, A.; Satyanarayana, T. Statistical optimization of the medium components by response surface methodology to enhance phytase production by Pichia anomala. Process Biochem. 2002, 37, 999-1004. [CrossRef]

31. Beg, Q.K.; Saxena, R.K.; Gupta, R. Kinetic constants determination for an alkaline protease from Bacillus mojavensis using response surface methodology. Biotechnol. Bioeng. 2002, 78, 289-295. [CrossRef] [PubMed]

Sample Availability: Samples of the compounds including acetophenone, 1-phenylethanol, and $\left[{ }^{2} \mathrm{H}_{5}\right]$ ring-acetophenone are available from the authors.

(C) 2017 by the authors; licensee MDPI, Basel, Switzerland. This article is an open access article distributed under the terms and conditions of the Creative Commons Attribution (CC-BY) license (http://creativecommons.org/licenses/by/4.0/). 